\title{
Physicochemical and fungal diversity analysis of two different sources of polluted water of Cachar District Assam
}

Rajesh Paul and Jashodeb Arjun

Zoology Department Lumding College Lumding 782447 Assam

\begin{abstract}
Analysis of physicochemical and fungal species from two different sources of water pollution, as Paper Mill Effluents (PME) of Hindustan Paper Corporation and City Domestic Sewage (DS) of Cachar district, Assam was carried out during pre and post monsoon season (February, 2016 and May, 2016). Water samples were collected and analyzed for standard physicochemical parameters where $\mathrm{pH}$, turbidity, electrical conductivity, total hardness were found within the limits prescribed by WHO and ISI where as total alkalinity, Total Dissolved Solids (TDS), nitrate and Phosphate content were found to be exceeding the permissible limits for both PME and DS. Aspergillus niger, A. flavus. and Penicillium citrinum were among the most commonly encountered species of fungi from both the sites. Highly significant microbial load was observed in domestic sewage $(\mathrm{cfu} / \mathrm{ml}=22.0 \times 103, \mathrm{P}<0.001)$ during the post monsoon season (May, 2016).
\end{abstract}

ABBREVIATIONS: PME: PAPER MILL EFFLUENT; DS: DOMESTIC SEWAGE

KEY WORDS: PAPER MILL EFFLUENTS, DOMESTIC SEWAGE, FUNGAL SPECIES, PHYSICO CHEMICAL PARAMETERS

\section{INTRODUCTION}

Water is the basic need of life, a precious gift of nature to man and all the living creatures of this universe. So the quality of water is of vital concern as it is directly linked with human welfare. Only 3\% of the water in the universe is fresh and among the fresh waters, only around

\section{ARTICLE INFORMATION:}

*Corresponding Author: paulrajesh966@gmail.com

Received $17^{\text {th }}$ June, 2017

Accepted after revision $25^{\text {th }}$ Sep, 2017

BBRC Print ISSN: 0974-6455

Online ISSN: 2321-4007 CODEN: USA BBRCBA

Thomson Reuters ISI ESC and Crossref Indexed Journal

NAAS Journal Score 2017: 4.31 Cosmos IF: 4.006

๑ A Society of Science and Nature Publication, 2017. All rights reserved.

Online Contents Available at: http//www.bbrc.in/

DOI: $10.21786 / \mathrm{bbrc} / 10.3 / 8$
$5 \%$ or $0.15 \%$ of the total water are available for use. The total water resource available in India is $1850 \mathrm{~km}^{3}$, which is approximately $4 \%$ of the worlds fresh water resources (EPA-PWD, 2001) . But very fast it is becoming a scare commodity in many parts of the universe.

The water quality monitoring results obtained during 1995 to 2006 indicate that the organic and bacterial 
contamination are continued to be critical in water bodies. This is mainly due to discharge of domestic wastewater mostly in untreated form from the urban centers of the country and at the same time the receiving water bodies also do not have adequate water for dilution. Therefore, the oxygen demand and bacterial pollution is increasing day by day which is mainly responsible for water borne diseases.

The total surface water resource of Assam State is estimated at about 600 billion cubic meters, where the annual replenishable groundwater resource of the State has been estimated as 27.23 billion cubic meters. But prolonged discharge of industrial effluents, domestic sewage and solid waste dump causes pollution in the water resources which leads to enormous health problems. The rapid growth of industrial resources has further affected water quality due to overexploitation and improper waste disposal practices. Hence there is always a need for concern over the protection and management of water resources .considering the above aspects of contamination ,the present study was undertaken to investigate the level of water pollution and at the same time to measure the microbial contamination due to industrial and domestic exposure in the country rivers.

\section{MATERIALS AND METHODS}

\section{SAMPLING SITE AND PREPARATION OF WATER SAMPLES}

The present study was carried out during the pre and post monsoon season (February, 2016 and May, 2016). Raw paper mill effluent sample was collected from the outlet pipes in the local river Barak. For comparative analytical study domestic sewage was collected from Silchar, Municipal drainage system at Tarapur area, where all the debris and discharges of the whole locality have been found to be discharged. Both the effluent and sewage samples were collected in plastic gallons, $\mathrm{pH}$ was measured and stored at $-20^{\circ} \mathrm{C}$ to prevent further microbial growth.

\section{PHYSICO-CHEMICAL PARAMETERS AND MICROBIAL DIVERSITY STUDY}

The paper mill effluent and domestic sewage were analyzed for a number of standard physico-chemical properties, including Color, temperature, $\mathrm{pH}$, turbidity, Dissolved Oxygen (D0), Electrical Conductivity (EC), Total alkalinity (TA), Total Dissolved Solids (TDS), Total Hardness (TH), $\mathrm{FCO}_{2}$, Nitrate and Phosphate content were analyzed followed by the standard methods (USEPA,1996; APHA, 1998).

For the isolation of fungi from both the effluent and sewage samples, serial dilution plate technique was used $.1 \mathrm{ml}$ of final dilution of sample was inoculated on Czapek Dox Agar medium. In sterile Petri dishes Martin's Rose Bengal was added as a bacteriostatic agent according to Smith and Dawson (1944). The tubes of colony forming units (cfu) was determined after incubating the inoculated plates in 3 replicates at $25^{\circ} \mathrm{C}\left( \pm 2^{\circ} \mathrm{C}\right)$ for $4-5$ days, thereafter fungal species were identified using the keys as described by Gilman (1957); Raper and Fennel (1965).

\section{STATISTICAL ANALYSIS}

Results were presented as Mean \pm SE followed by microbial diversity studies where mean value was calculated from three individual readings of a particular set. ANOVA was performed to determine the level of significance of microbial diversity studies. ANOVA was done using graph pad PRISM (Graph pad Inc., san Diego, CA, USA). Percentage occurrence used in this study include,

Occurrence of Species A

Percentage occurrence of species $=$ Í 100

Occurrence of all species

\section{RESULTS AND DISCUSSION}

The result of physicochemical parameters performed from both paper mill effluent and domestic sewage are presented in Table 1 and 2.

\section{$\mathrm{PH}$}

$\mathrm{pH}$ is used to express the intensity of acid or alkaline condition of a water sample. In our case $\mathrm{pH}$ value ranged from 4.78-6.74, found within the permissible limits. Highly acidic $\mathrm{pH}$ was recorded in DS in both the seasons specially during the month of May. Water samples with low $\mathrm{pH}(<6.0)$ attributes to the discharge of acid contents into these effluents by agricultural or domestic activities. A decrease in $\mathrm{pH}$ may be caused by the increase in the amount of organic carbon, total carbonates available in the sewage resources. Though $\mathrm{pH}$ has no direct effect on human health still the different kinds of biochemical reactions taking place within human body are sensitive to variation of $\mathrm{pH}$.

\section{TURBIDITY}

Turbidity is due to colloidal and fine dispersions in water resources. The turbidity value varied between 2.5-3.2 and found within the permissible limit of WHO and ISI.

\section{DISSOLVED OXYGEN (DO)}

Dissolved Oxygen is an important parameter for water quality assessment which reflects the biological pro- 
Table 1. Physico chemical characteristics of PME and DS in the month of February, 2016.

\begin{tabular}{|l|c|c|c|c|}
\hline Parameters & $\begin{array}{c}\text { Paper Mill } \\
\text { Effluent (PME) }\end{array}$ & $\begin{array}{c}\text { Domestic } \\
\text { Sewage (DS) }\end{array}$ & $\begin{array}{c}\text { WHO } \\
\text { Standards }\end{array}$ & $\begin{array}{c}\text { ISI } \\
\text { Standards }\end{array}$ \\
\hline Color & Pale brown & Dark brown & - & - \\
\hline Temperature & 28 & 24 & - & - \\
\hline $\mathrm{pH}$ & 6.16 & 4.78 & $6.5-8.5$ & $6.5-8.5$ \\
\hline Turbidity & 2.5 & 2.8 & 5.0 & 10 \\
\hline Dissolved Oxygen (D0) & 23.24 & 4.44 & - & 5.0 \\
\hline Electrical conductivity (EC) & 0.9 & 1.9 & 1400 & \\
\hline Total Alkalinity & 460 & 355 & 120 & 200 \\
\hline Total Hardness & 214.67 & 138.67 & 500 & 300 \\
\hline FCO ${ }_{2}$ & 7.34 & 14 & - & - \\
\hline Total Dissolved Solids (TDS) & 665 & 3695 & 1000 & 500 \\
\hline Nitrate & 7.942 & 8.414 & 5 & 45 \\
\hline Phosphate & 2.192 & 3.778 & 0.1 & - \\
\hline
\end{tabular}

Table 2 . Physico chemical characteristics of PME and DS in the month of May, 2016.

\begin{tabular}{|c|c|c|c|c|}
\hline Parameters & $\begin{array}{l}\text { Paper Mill Effluent } \\
\text { (PME) }\end{array}$ & $\begin{array}{c}\text { Domestic } \\
\text { Sewage (DS) }\end{array}$ & $\begin{array}{c}\text { WHO } \\
\text { Standards }\end{array}$ & $\begin{array}{c}\text { ISI } \\
\text { Standards } \\
\end{array}$ \\
\hline Color & Pale brown & Dark brown & - & - \\
\hline Temperature & 26 & 23 & - & - \\
\hline $\mathrm{pH}$ & 6.74 & 5.12 & $6.5-8.5$ & $6.5-8.5$ \\
\hline Turbidity & 2.7 & 3.2 & 5.0 & 10 \\
\hline Dissolved Oxygen (D0) & 17.96 & 3 & - & 5.0 \\
\hline Electrical conductivity (EC) & 1.2 & 2.1 & 1400 & \\
\hline Total Alkalinity & 417 & 323 & 120 & 200 \\
\hline Total Hardness & 298.67 & 202.66 & 500 & 300 \\
\hline $\mathrm{FCO}_{2}$ & 14.34 & 24.67 & - & - \\
\hline Total Dissolved Solids (TDS) & 617 & 3432 & 1000 & 500 \\
\hline Nitrate & 8.123 & 9.235 & 5 & 45 \\
\hline Phosphate & 2.431 & 4.537 & 0.1 & - \\
\hline
\end{tabular}

Table 3. Result of microbial (fungal) diversity isolated from PME and DS (February, 2016 and May, 2016).

\begin{tabular}{l|c|c|}
\multirow{2}{*}{$\begin{array}{l}\text { Treatment } \\
\text { Groups }\end{array}$} & \multicolumn{2}{|c|}{ cfu /ml (x 103) } \\
\cline { 2 - 3 } & February, 2016 & May, 2016 \\
\hline Paper Mill & $4.67 \pm 0.17$ & $5.67 \pm 0.45$ \\
Effluent (PME)(\%) & $9.34 \mathrm{a} \pm 0.45$ & $10.34 \mathrm{~b} \pm 1.2$ \\
10 & $10.67 \mathrm{~b} \pm 0.45$ & $19.34 \mathrm{a}, \mathrm{b} \pm 0.75$ \\
25 & & \\
50 & & \\
Domestic Sewage & $7.34 \pm 0.34$ & $8.0 \pm 0.78$ \\
(DS) (\%) & $13.67 \mathrm{c}, \mathrm{b} \pm 0.45$ & $12.67 \mathrm{~b} \pm 1.047$ \\
10 & $15.67 \mathrm{c}, \mathrm{b}, \mathrm{a} \pm 0.75$ & $22.0 \mathrm{~b}, \mathrm{c}, \mathrm{a} \pm 1.95$ \\
25 & & \\
50 & & \\
\hline \multicolumn{2}{|l}{ Where, $\mathrm{P}<0.05=\mathrm{a}, \mathrm{P}<0.01=\mathrm{b}, \mathrm{P}<0.001=\mathrm{c}$} \\
\hline
\end{tabular}

cesses taking place in water bodies. The DO value indicates the degree of pollution in water .In our study the DO content was found minimum during the month of May, which may be because the increased algal productivity due to increased rate of photosynthesis (Rajkumar et al, 2004).

\section{ELECTRICAL CONDUCTIVITY (EC)}

Electrical conductivity is a measure of water capacity to convey electrical current. It signifies the amount of total dissolved salts. EC value was found within the range of 0.9-2.1 micromho / cm where DS showed higher EC value in both the seasons indicating the presence of high amount of dissolved inorganic substances in the ionized 
Table 4. Occurrence of fungi isolated from PME and DS (February, 2016 and May, 2016)

\begin{tabular}{|c|c|c|c|c|c|c|c|c|c|c|c|c|}
\hline \multirow{4}{*}{$\begin{array}{l}\text { Fungal Species } \\
\text { Identified }\end{array}$} & \multicolumn{12}{|c|}{ Water Samples } \\
\hline & \multicolumn{6}{|c|}{ Paper Mill Effluent (PME) } & \multicolumn{6}{|c|}{ Domestic Sewage (DS) } \\
\hline & \multicolumn{2}{|c|}{$10 \%$} & \multicolumn{2}{|c|}{$25 \%$} & \multicolumn{2}{|c|}{$50 \%$} & \multicolumn{2}{|c|}{$10 \%$} & \multicolumn{2}{|c|}{$25 \%$} & \multicolumn{2}{|c|}{$50 \%$} \\
\hline & Feb & May & Feb & May & Feb & May & Feb & May & Feb & May & $\mathrm{Feb}$ & May \\
\hline A. flavus & 42.85 & 47.05 & 50 & 38.7 & 50 & 39.65 & 27.27 & 0 & 31.7 & 0 & 31.91 & 0 \\
\hline A. niger & 0 & 41.17 & 0 & 48.38 & 0 & 44.82 & 45.45 & 44.45 & 39.02 & 50 & 40.42 & 56.06 \\
\hline Penicilliumcitrinum & 28.57 & 11.76 & 21.42 & 12.9 & 25 & 15.51 & 9.09 & 0 & 9.75 & 0 & 10.63 & 0 \\
\hline A. fumigatus & 0 & 0 & 0 & 0 & 0 & 0 & 18.18 & 51.85 & 19.51 & 42.1 & 17.02 & 31.81 \\
\hline Mucor sp. & 14.28 & 0 & 17.85 & 0 & 15.625 & 0 & 0 & 3.7 & 0 & 7.89 & 0 & 6.06 \\
\hline Rhizopus sp. & 14.28 & 0 & 14.28 & 0 & 9.375 & 0 & 0 & 0 & 0 & 0 & 0 & 0 \\
\hline
\end{tabular}

form in domestic sewage as the conductance of water increases with salts. Higher the concentration of electrolyte in water the more is its electrical conductance.

\section{TOTAL ALKALINITY}

The alkalinity of water is caused mainly due to $\mathrm{OH}, \mathrm{CO}_{3}$, $\mathrm{HCO}_{3}$ ions, borates, phosphates and organic acids. It is an estimation of the ability of water to resist change in $\mathrm{pH}$ upon addition of acid. In the present study, alkalinity was found beyond the permissible limits of both WHO and ISI standards. Maximum alkalinity may be due to low temperature bringing down the rate of decomposition of salts to a minimum thus by increasing alkalinity.

\section{TOTAL HARDNESS}

Water hardness is a measure of capacity of water to precipitate soap. It is defined as the sum of Calcium and Magnesium concentration, both expressed as Calcium carbonate. In the present investigation, the Total Hardness value (138.67-298.67 mg/L) ranged within the permissible limits with maximum hardness during summer (May), which might be due to reduced inflow of water and rate of evaporation. The $\mathrm{FCO}_{2}$ value was recorded minimum in PME specially in February, 2010 which may be due to less suspended microbial load on suspended particles and algal masses (Michael, 1984).

\section{TOTAL DISSOLVED SOLIDS (TDS)}

TDS content was found within the range of 617-3695 $\mathrm{mg} / \mathrm{L}$ where DS showed higher TDS content specially in pre monsoon season which exceeded the maximum permissible limit of ISI Standards indicating the enormous storage of different types of salts such as carbonates, bicarbonates, chlorides, phosphates, nitrates, magnesium calcium, sodium, potassium, manganese and organic matters.

Nitrate and Phosphate content were found at higher concentrations in domestic sewage specially in the summer season (May, 2010) where Nitrate and Phosphate level for both the effluents exceeded the permissible limit of WHO Standards. Higher Phosphate concentration may be because of the discharge of domestic wastes, soaps, detergents, fertilizers and human activities.

All together six species of fungi belonging to four genera were isolated and identified from the water samples. The majority of fungi were encountered rarely. Of the genus Aspergillus the best represented species were Aspergillus niger, A. fumigatus A. flavus. and Penicillium citrinum which were isolated from PME as well as from DS. The fungi isolated from different samples of Barak River were likely to be originated from soil or entered the water with plant remains. The isolated fungi from river Barak belong mainly to the category of transient accidental microorganisms, according to ecological classification of aquatic heterotrophic microorganisms (Park, 1972b). Transient and accidental microorganisms can develop sporadic activity and soil fungi may participate in microbiological processes in water bodies (Park, 1972b). Among the fungal population Aspergillus was represented by highest number of species. This is in accordance with the statement of Barron (1968) that Aspergillus is biologically one of the most successful of all fungi and is expected to occur on all sorts of organic debris. Carlie and Watkinson (1997) in their study observed that Aspergillus and Penicillium sp have cellulolytic enzymes and wood degrading capability. Cellulolytic filamentous fungi have the ability to penetrate cellulose substrate through hyphal extensions. cfu rate was found to be highly significant in DS $\left(22.0 \times 10^{3}\right)$ especially in summer followed by. ANOVA. Low cfu rate in February may be due to cold climatic condition inhibiting fungal growth. Maximum fungal diversity was recorded in domestic sewage in comparison to PME. Higher occurrence of A. flavus and Penicillium citrinum. was noted in PME where as $A$. niger and A. fumigatus were among the mostly encountered species in DS in both the seasons.

\section{CONCLUSION}

As the river water is being purified by the municipal corporations before public consumption, so human being 
have least possibilities to get effected as the effluents and sewages get diluted in the river and after purification possibilities to develop water borne disease becomes negligible. But aquatic flora and fauna are directly getting exposed to the water of river Barak , might be tremendously effected by the exposure of this polluted water specially in the form of microbial contamination as no precautions have been undertaken yet for the safety of aquatic ecosystem including the aquatic plants and organisms specially fishes. So, proper measures have to be undertaken for the maintenance of water quality in Barak river, so that the water quality and aquatic life including the aquatic flora and fauna can be protected from microbial contamination and water pollution as well.

\section{ACKNOWLEDGEMENT}

We are grateful to UGC for providing fellowship to RP and BR.

\section{REFERENCES}

American public health Association: Standard methods for the examination of water and wastewater 20th edition, APHA, AWWA, WPCF, Washington DC (1998).

Barron, G.L.: The genera of Hyphomycetes from soil. Williams and Wilkins Co, Baltimore (1968).

Bennett, J. W.: Klich, M.A. Mycotoxins. Clin. Microbiol. Rev. 16: 497-516 (2003).

Bitton, G .: Waste Water Microbiology.Gainesville, New York Wiley- Liss. 118p(1994).

Carlie, M.J., Watkinson, S.C .: The fungi. Academic Press, New York., pp. 269-275(1997).

Edema, M.O., Omemu, A.M., and Fapetu, O.M.: Microbiological and physicochemical analysis of different sources of drinking water. Nigerian Journal of Microbiology 15: 57-61(2001).
Environmental Planning Frame Work for Water Resources Management in Tamil Nadu, Final Draft, Public Works Department, Government of Tamil Nadu (2001).

EPA: US Environmental Protection Agency Safe Drinking Water Act.EPA 816-F-03-016 (2003).

Gilman, J.D.: A manual of soil fungi ,lowa state univ,press, Amer, lowa, USA, pp: 450 (1957).

ISI:10500 (1991): Indian standards of Drinking Water Specification, Bureau to Indian Standards (BIS),New Delhi, India.

ISI (1982): Tolerance limit for inland surface water subject to pollution, 2296, Indian Standards Institute, New Delhi, India.

Manivasakam, N.: Physical Chemical examination of water, sewage and industrial effluents 5th Ed, Pragati Prakashan, Meeret, India (2005)

Michael, P. Ecological Methods for Field and Laboratory Investigations. Tata Mc Graw Hill, New Delhi. 1984; pp- 434.

Park, D.: On ecology of heterotrophic microorganisms in freshwater. Transactions of the British mycological Society 58: 291299 (1972b).

Rajkumar, S.,Velmurugan. P., Shanti, K., Ayyasamy, P.M., and Lakshmanaperumalsamy, P. Water Quality of Kodaikanal Lake, Tamilnadu in relation to physico-chemical and bacteriological characteristics, Capital Publishing Company, Lake 2004, pp.339-346.

Raper, K.B and Fennel, D.J. The Genus Aspergillus Williams and Wilkins, Baltimars, pp:686 (1965).

Smith, N.R. and Dawson, T.V.: The bacteriostatic action of rose Bengal in media used for the plate counts of soil fungi, Sill Sel, 58; 467-491(1944) .

United States Environmental Protection Agency: Acid digestion of sediments sludge and soils. Method-3050B, USEPA, Washington, DC (1996).

World Health Organization: Guidelines for drinking water quality. World Health Organization, Geneva, Switzerland (1992).

World Health Organization: Guidelines for drinking water quality-I, recommendations Geneva, WHO, $2^{\text {nd }}$ Ed. (1993). 